
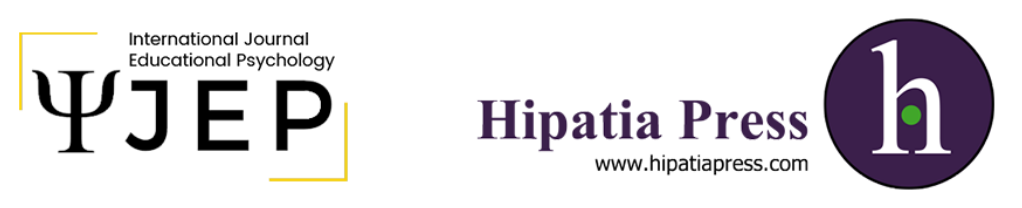

http://ijep.hipatiapress.com

\title{
Academic Progress, Coping Strategies and Psychological Distress among Teacher Education Students
}

Josep Gustems-Carnicer ${ }^{1}$, Caterina Calderon ${ }^{1}$, Diego Calderon-Garrido', Carolina Martin-Piñol ${ }^{1}$

${ }^{1}$ University of Barcelona, Spain

Date of publication: October $24^{\text {th }}, 2020$

Edition period: October 2020 - February 2021

To cite this article: Gustems-Carnicer, J., et al (2020). Academic Progress, Coping Strategies and Psychological Distress among Teacher Education Students. International Journal of Educational Psychology, 9(3), 290-312. doi: 10.17583/ijep.2020.4905

To link this article: $\underline{\text { http://dx.doi.org/10.17583/ijep.2020.4905 }}$

PLEASE SCROLL DOWN FOR ARTICLE

The terms and conditions of use are related to the Open Journal System and to Creative Commons Attribution License (CC-BY). 


\title{
Academic Progress, Coping Strategies and Psychological Distress among Teacher Education Students
}

Josep Gustems-Carnicer, Caterina Calderon, Diego Calderon-Garrido, Carolina Martin-Piñol

University of Barcelona

\begin{abstract}
Academic performance among university students is a fundamental factor in the analysis of quality of higher education. Despite the large volume of research on academic performance, there are no conclusive results regarding the influence of some variables on it. While some studies find differences attributable to gender, age, or psychological factors, such as coping strategies, others conclude that they are inexistent or insignificant. This article seeks to deepen about how these variables influence the academic performance of trainee primary-school teachers. Educational improvements in a society are only possible if teacher training guarantees a high qualification of its teachers. In this article we analyze academic progress in a sample of 136 students and the effect of gender, age and coping strategies and psychological symptoms. From the data analysis it can be concluded that all the analyzed variables cause differences in academic performance in teacher students. Therefore, it will be necessary to establish improvement plans for this degree that meet these conditions.
\end{abstract}

Keywords: academic progress, teacher training, coping strategies, stress. 


\section{Progreso Académico, Estrategias de Afrontamiento $\mathrm{v}$ Malestar Psicológico en Estudiantes de Maestro}

Josep Gustems-Carnicer, Caterina Calderon, Diego Calderon-Garrido, Carolina Martin-Piñol

University of Barcelona

\section{Resumen}

El rendimiento académico es un factor fundamental en la calidad de la educación superior. A pesar del gran volumen de investigaciones sobre el rendimiento académico no hay resultados concluyentes respecto a la influencia de algunas variables sobre el mismo. Mientras que algunos estudios encuentran diferencias atribuibles al género, la edad o a factores psicológicos como las estrategias de afrontamiento, otros concluyen que son inexistentes o insignificantes. Este artículo busca profundizar acerca de cómo dichas variables influyen en el desempeño de los estudiantes del grado de maestro en educación primaria. Las mejoras educativas en una sociedad sólo son posibles si la formación docente garantiza una alta cualificación de su profesorado. En este artículo se analiza el progreso académico en una muestra de 136 estudiantes y el efecto del género, la edad y las estrategias de afrontamiento y los síntomas psicológicos. Del análisis de los datos puede concluirse que todas las variables analizadas provocan diferencias en el rendimiento académico en los estudiantes de maestro, por lo que será necesario establecer planes de mejora de esta titulación que atiendan tales condiciones.

Palabras clave: progreso académico, formación de maestros, estrategias de afrontamiento, estrés. 


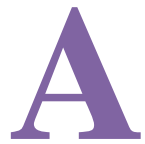

cademic progress is a variable of great importance for all university studies, and especially those involving primary-teacher education students. Society can only be improved if university education produces high-quality teachers (Maandag et al., 2017). Developments in our society are rapid and schools and teachers are expected to adapt to them and if possible spur them on (Hofman, Hofman, \& Gray, 2015).

Entering university is an inherently stressful and demanding transition (Kwan et al., 2016). Students find themselves in a new, changeable and competitive environment, and for many it is their first opportunity to experience the sensation of independence and responsibility. This usually occurs when they are about 18 years old and during their time at university, they will face numerous challenges and difficulties. To complete their studies, they will develop competencies and adopt coping strategies that will subsequently help or hinder them in their adaptation to the world of work.

A large number of factors contribute to explaining university students' academic progress (Gustems et al., 2019), including academic pressure (Kember \& Leung, 2006), excessive workload, financial problems, and personal circumstances (Singh \& Upadhyay, 2008). Knowing students' concerns is a subject of particular interest for those working in higher education, since it can assist them in better understanding what undergraduates are going through. In this regard, various authors have discovered differences between men and women in matters related to students' health and eating habits: women are more prone to suffering stress, perceiving themselves to be in poor health and having a higher prevalence of unhealthy eating behaviours than men (Varela-Mato et al., 2012). At the same time, male students tend to employ fewer coping strategies, seek less help from their fellow students and try to sort out their problems alone (Hsieh et al., 2014). Enlisting social support is a relevant factor in the university context, which is an environment that fosters peer and student-teacher relationships. It is therefore important that students take advantage of such interactions to exchange information, establish networks and develop new personal and social skills.

Various authors have related stress to coping strategies, specifically to avoidance coping (Holahan et al., 2005). Avoidance coping involves cognitive and behavioural efforts oriented toward denying, minimizing, or 
otherwise avoiding dealing directly with stressful demands and is closely linked to distress (Aldwin et al., 2018). For example, cognitive avoidance against incipient stressors such as difficulties with fellow students or teachers, or of a financial nature that are constantly put off or avoided, may eventually become the source of major problems in the future. Behavioural avoidance may lead to the awakening of new stressors; for example, emotional discharge may further aggravate existing tensions with the family or at work (Holahan et al., 2005). Avoidance coping has also been linked to the increased presence of depressive symptoms in university students (Hye-Yun, 2016). In women, the association between avoidance coping and depression has been related to rumination, defined as a passive coping strategy and more frequent in women than men, which is linked to intensive, persistent depressive symptoms (Holahan et al., 2005).

It would also appear that stress levels are generally higher in the first and last years of the degree (Deasy et al., 2016), and especially in the first academic term (Bewick et al., 2010).Some authors suggest that the university context brings out more anxiety than depression because students have to face new environments with formidable intellectual and relational demands, and thus younger individuals tend to be more vulnerable. Moreover, those students who suffer the greatest emotional toll are most prone to experiencing burnout later in their professional career (McCarthy et al., 2017).

In the Spanish context, teacher training studies consist of a 4-year university degree with a workload of 240 credits, which represents a dedication about 30 hours of class per week, in addition to the effort that they must make to complete their apprenticeships and group work. In some cases, this represents a handicap for combining studies with part-time jobs, which contributes to the overload of effort and brings students closer to sources of stress.

Analysis of the factors determining whether undergraduates will successfully complete their university courses is of huge importance, especially in the case of teacher education students, who will have the responsibility of educating future generations. Previous research indicates that academic progress may be affected by a wide variety of academic, cognitive, demographic and psychological factors (Coertjens et al., 2017). Student gender and age also have a significant impact on performance: proportionally fewer men and younger students complete their studies (Jenzer et al., 2019). 
Likewise, the academic progress of women tends to be higher than that of their male counterparts (Reilly, Neumann, \& Andrews, 2015), as does that of the older students (Farley, Clayton, \& Kaka, 2018).

Essentially, the literature indicates that psychological distress is related to coping strategies and that both have implications for academic progress. However, relatively few studies analyze psychological distress, coping and academic progress in teacher education students, comparing academic performance in men and women. This study analyzes a sample of teacher education undergraduates, and has three objectives: 1) to describe the problems the students express, and analyze their differences by gender; 2) to compare coping strategies and psychological symptoms on the basis of gender and age; and 3) to analyze the predictive relationship of coping strategies and psychological symptoms in the academic progress of men and women.

\section{Participants}

\section{Method}

A convenience sample of 136 undergraduate college students (68 men and 68 women) of the University of Barcelona was studied. The average age of the total sample was 24.2 years $(S D=5.5$, range 19-39). The average age for men was 25.1 years $(S D=5.8)$ and for women it was $23.7(S D=5.2)$, no significant differences between them $(t=1.399, p=.164)$. The educational grade of the total population were 14.7\% $(n=20)$ students of Early Childhood Education Degree and $85.3 \%(n=116)$ were students of Primary Education Degree. With regard to the academic year, $11.8 \%(n=16)$ were in second year, $55.9 \%(n=$ $76)$ in third year, and $32.4 \%(n=44)$ in fourth year.

Based on Hollingshead four factor index (Hollingshead 2011), the participants' families corresponded to the following categories: 13.4\% low Family Socioeconomic Status (FSS), 16.1\% FSS low-medium, 23.6\% FSS medium, $32.9 \%$ FSS medium-high, and $13.7 \%$ FSS high. The average FSS for men was $42.2(S D=15.8)$ and for women was $44.5(S D=12.1)$, no significant differences between them $(t=-.941, p=.348)$, see Table 1 . 
Table 1

Descriptive statistics of relevant variables $(n=136)$

\begin{tabular}{|l|c|c|c|c}
\hline Variables & Men & Women & $t$ & $p$ \\
\hline Age. M (SD) & $25(5.8)$ & $23.7(5.2)$ & 1.399 & .164 \\
\hline Academic year. n (\%) & & & .000 & 1.000 \\
\hline $2^{\text {on }}$ year & $8(11.8)$ & $8(11.8)$ & & \\
\hline $3^{\text {rd }}$ year & $38(55.9)$ & $38(55.9)$ & & \\
\hline $4^{\text {th }}$ year & $22(32.4)$ & $22(32.4)$ & & \\
\hline Bachelor degree. $\mathrm{n}(\%)$ & & & .000 & 1.000 \\
\hline$\quad$ Early childhood education & $10(14.7)$ & $10(14.7)$ & & \\
\hline$\quad$ Primary education & $58(85.3)$ & $58(85.3)$ & & \\
\hline$\quad$ Not provide information & $2(.6)$ & $2(.6)$ & & \\
\hline FSS family. M (SD) & $42.2(15.8)$ & $44.5(12.1)$ & -.941 & .348 \\
\hline Completed academic credits. M (SD) & $142(47.7)$ & $146.8(51.0)$ & -.563 & .575 \\
\hline Grade-Point Average M (SD) & $7.5(.41)$ & $7.6(.47)$ & -1.871 & .064 \\
\hline
\end{tabular}

\section{Measures}

The following questionnaires were administered:

The socio-demographic data sheet provided information about some characteristics of the group: age, gender, year of study, degree being studied, and Family Socioeconomic Status (FSS, Hollingshead, 2011). For the FSS, education and occupation levels of both parents were taken into account.

Coping Reponses Inventory-Adult Form, CRI-A (Moos, 1993) was used to obtain an indication of the respondents' coping strategies. The Spanish adaptation (Kirchner et al., 2008) of the Coping Responses Inventory-Adult Form (CRI-A) was employed.

The test is structured in two parts: in the first, subjects describe the most difficult event or problem they have had to deal with in the last 12 months; in the second, they respond to 48 questions directly related to the type of coping strategy they employed to resolve the situation described. In assessing the issues the students explained, we followed the coding system based on work carried out by Forns et al. (2004), which breaks the problem down into four categories: nature, content, participants and context. The nature category identifies who is suffering the problem, which it organises into three subcategories: personal, interpersonal and problems of others. The content category identifies the substance of the problem, meaning the facts, 
circumstances or events that comprise it, and consists in 13 sub-categories: problems of relationships, divorce, guilt, performance, and change of residence, conflicts with rules, victimization, leisure activities, health, addictions, money-work, death, and others. The category of participants refers to those who are essentially involved in the conflictive situation, and comprises eight sub-categories: the subject, his or her immediate family or extended family or both, partner, teachers, adults and animals. The context category identifies the framework or setting in which the problem occurs and includes five sub-categories: home and extended family, school, leisure time, neighbourhood and other settings, and others.

To evaluate the coping strategies, the 48 items that require participants to indicate their responses on a four-point Likert scale anchored by 'not at all' and 'fairly often'. These responses are measured by four scales: two scales measure approach coping and two scales measure avoidance coping (Moos, 1993). The cognitive approach coping strategies include: logical analysis and positive reappraisal. The behavioural approach coping strategies comprehend: seeking guidance and support, and problem solving. The cognitive avoidance coping strategies include: cognitive avoidance and acceptance/resignation. The behavioural avoidance coping strategies comprise: seeking alternative rewards and emotional discharge. The reliability coefficient of the CRI-Adult ranges from .58 to .74, thus indicating moderate to high internal consistency for the test. The Spanish adaptation of the CRIAdult shows good reliability, with Cronbach's alpha coefficients ranging between .81 and .90 . The CRI-Adult is considered to be valid and has been used extensively by researchers (Patiño \& Kirchner, 2010).

Brief Symptom Inventory. The BSI-18 (Derogatis, 2001) was used to measure participants' psychological distress. This inventory includes 18 symptoms to assess the degree of distress on a Likert-type five-point scale, ranging from 1 (total absence of symptom) to 5 (full presence of symptom). The scale provides three groups of symptoms: somatization, depression, and anxiety, and a global severity index (GSI). The test-retest reliability ranged from .78 to .90. Cronbach's alpha ranged from .81 to .90 (Derogatis, 2001).

Academic Progress (GPA). The students specified their university gradepoint average and the number of academic credits they had successfully completed. The formal curriculum was meant to be completed in 4 years; however, the system was somewhat flexible and a number of students took 
longer to complete their studies. Grade-Point Average (GPA) was considered as an indicator of academic progress. Students have access to this information in their intraweb personal space, and it is the information provided in this study.

\section{Procedure}

The students of Early Childhood Education Degree and Primary Education Degree were mostly women (4:1 or 3:1, respectively). We want to analyze the differences in men and women regarding the academic progress, coping and psychological symptoms. A total of 94 men from different degree years were invited to take part in the study, of whom 68 accepted and 26 declined (27.6\%); the participation of 68 women from the same classes was sought, so invitations were extended to 80 , of whom 12 declined (15\%).

The questionnaires were applied collectively in groups of 10-20 students over one-hour session in their usual class, accompanied by one or two members of the research team to clarify doubts and help if necessary. This study was approved by the Ethics Committee of the University of Barcelona (Spain) and was conducted in line with the guidelines of the Belmont Report (1978). A consent form to be signed by students was requested the day of the data collection. The participation of study was voluntary and anonymous.

\section{Data Analysis}

The characteristics of the students were described. In the case of the quantitative variables, means and standard deviations were calculated; frequencies and percentages were used for qualitative variables. The reliability analysis of the coding problem has been conducted by Cohen Kappa index. Two independent psychologists, properly trained, coded problems. The index was found Kappa Cohen between coders taken in pairs, and the average value of the two index was calculated. The differential analysis by gender of the different categories of problems has been made by $\mathrm{X} 2$ technique and calculation of percentage differences. To maintain a nominal rate of type I error is .05 . Bonferroni correction applied. Student's $t$-test was used to assess the statistical significance of the difference between gender and age. Bivariate correlations were calculated between academic progress, coping strategies and psychological distress by gender.

Linear regression analysis were used for predicting the relationship between coping strategies and psychological distress in academic progress by 
gender in college students. Here, the stepwise method was employed. In the subsequent statistical analysis, university grade-point average served as the predictor variable in the regression analysis, while coping strategies (as measured by the CRI-A), and psychological distress (as measured by the BSI18), was utilized as the criterion variable. The study used a stepwise selection method and, for the statistical analysis, Version 22.0 of the Statistical Package for the Social Sciences (SPSS). For all the tests carried out, bilateral statistical significance was set at $p$ equal to or less than .05 .

\section{Results}

\section{Problems expressed by students by category and gender}

Depending on the nature of the problem, male students describe problems they directly involves themselves (44.5\%), and linked to the subject's relationship with other people $(33.3 \%)$. In women, the problem described directly affected themselves $(34.6 \%)$ or with the others $(34.6 \%)$.

About the content, in male students $33.3 \%$ problems appear in the subject's relationship with others, and $26 \%$ the problem is limited to guilt, worry, restlessness and dissatisfaction that the subject experiences himself. In women, the problems are due to conflicts with other persons $(30.7 \%)$ or are problems due to the onset of disease in $23 \%$ of cases. Women described more problems related to health issues than men, statistically significant differences $(Z=.029, p=.024)$.

As participation in the problem, in $37 \%$ of men, the protagonist is the individual himself and another $37 \%$ are involved in the problem friends or colleagues of the subject. In women, $28.8 \%$ are problems that are involved in themselves and in $15.4 \%$ the problem occurs between them and their friends. Men described problems involving friends or colleagues more than women $(Z$ $=.046, p=.031$ ).

Depending on the area of occurrence of the problem, in male students, $37 \%$ the problem arises in the employment context, and by $26 \%$ the problem occurs in the family context. In women, $34.6 \%$ the problem occurs in the neighbourhood and physical and occupational contexts, and in $28.8 \%$ the problem occurs in the context of the nuclear family or extended family. See table 2 . 
Table 2

Classification of problems into categories (CRI-A). Percentages and significance by gender

\begin{tabular}{|c|c|c|c|c|}
\hline Categories of problem & $\%$ Men & $\%$ Women & $Z$ & $p$ \\
\hline \multicolumn{5}{|l|}{ Nature of the problem } \\
\hline Personal & 44.5 & 34.6 & .466 & .270 \\
\hline Interpersonal & 33.3 & 30.8 & .805 & .505 \\
\hline Others & 22.2 & 34.6 & .309 & .191 \\
\hline \multicolumn{5}{|l|}{ Content of the problem } \\
\hline Relationships & 33.3 & 30.7 & .805 & .505 \\
\hline Divorce & 3.7 & 1.9 & 1.000 & .570 \\
\hline Guilt & 26 & 15.4 & .365 & .202 \\
\hline Academic performance & - & - & - & - \\
\hline Change of residence & - & - & - & - \\
\hline Conflicts with rules & - & 5.7 & - & - \\
\hline Victimisation & - & - & - & - \\
\hline Sport, leisure & - & - & - & - \\
\hline Health & 3.7 & 23 & .029 & .024 \\
\hline Addictions & 3.7 & - & - & - \\
\hline Money, work & 14.8 & 3.9 & 1.000 & 612 \\
\hline Death, suicide & 14.8 & 15.5 & .435 & .267 \\
\hline Others & - & 3.9 & - & - \\
\hline \multicolumn{5}{|l|}{ Participants } \\
\hline Oneself & 37 & 28.8 & .459 & .311 \\
\hline Immediate family & 26 & 33 & .612 & .362 \\
\hline Extended family & - & 1.9 & - & - \\
\hline Fellow students, friends & 37 & 15.4 & .046 & .031 \\
\hline Partner & -- & 11.5 & - & - \\
\hline Teachers & -- & 3.8 & - & - \\
\hline Adults & -- & 5.6 & - & - \\
\hline \multicolumn{5}{|l|}{ Context of the occurrence } \\
\hline Home & 26 & 34.6 & .611 & .300 \\
\hline School & 7.4 & 1.9 & .268 & .268 \\
\hline Leisure, work & 14.8 & 19.3 & 1.000 & .596 \\
\hline Neighbourhood & 37 & 28.8 & .497 & .435 \\
\hline Non-specific & 14.8 & 15.4 & 1.000 & .612 \\
\hline
\end{tabular}

\section{Gender differences in coping, psychological scales and academic progress}

The coping strategies used by gender (Table 3 ) show that both men and women mainly used avoidance coping behaviour $(M=51.2, S D=6.4$ for men, and $M=52, S D=7.4$ for women), strategies as emotional discharge with 
others persons, involvement in risky activities, relaxing or pleasure activities, etc. Comparing strategies between both genders, women use more cognitive strategies than men (logical analysis $[t=2.071, p=.040]$ and acceptance or resignation $[t=2.245, p=.026])$. Likewise, the index of psychological distress is higher in women than in men $(t=2.376, p=.019)$, as well as somatization $(t=2.043, p=.043)$. Women show significantly more somatic problems and psychological distress than men.

Table 3

Mean differences by gender in coping (CRI-A), psychological symptoms (BSI) and academic progress (GPA)

\begin{tabular}{|c|c|c|c|c|}
\hline Coping Strategies & $\begin{array}{c}\text { Men } n=68 \\
\text { M (SD) }\end{array}$ & $\begin{array}{c}\text { Women } n=68 \\
\mathrm{M}(\mathrm{SD})\end{array}$ & $t$ & $p$ \\
\hline $\begin{array}{l}\text { Approach cognitive } \\
\text { coping }\end{array}$ & $49.5(8.0)$ & $51.2(6.3)$ & -1.348 & .180 \\
\hline Logical analysis & $47.8(10.5)$ & $51.1(7.3)$ & -2.071 & .040 \\
\hline Positive reappraisal & $51.2(7.7)$ & $51.3(8.5)$ & -.084 & .933 \\
\hline $\begin{array}{l}\text { Approach behaviour } \\
\text { coping }\end{array}$ & $47.1(8.9)$ & $49.1(6.5)$ & -.789 & .432 \\
\hline Seeking guidance & $49.9(10.2)$ & $49.0(7.5)$ & .615 & .540 \\
\hline Problem solving & $46.2(9.9)$ & $49.9(8.4)$ & -1.944 & .054 \\
\hline $\begin{array}{l}\text { Avoidance cognitive } \\
\text { coping }\end{array}$ & $49.6(8.0)$ & $51.2(8.1)$ & -1.151 & .252 \\
\hline Cognitive avoidance & $51.4(11.8)$ & $51.2(9.4)$ & .128 & .898 \\
\hline $\begin{array}{l}\text { Acceptance or } \\
\text { resignation }\end{array}$ & $47.7(7.4)$ & $51.2(10.1)$ & -2.245 & .026 \\
\hline $\begin{array}{l}\text { Avoidance behaviour } \\
\text { coping }\end{array}$ & $51.2(6.4)$ & $52.0(7.4)$ & -.689 & .488 \\
\hline $\begin{array}{l}\text { Seeking alternative } \\
\text { rewards }\end{array}$ & $50.7(10.2)$ & $52.9(11.3)$ & -1.189 & .237 \\
\hline Emotional discharge & $51.7(8.7)$ & $51.7(7.9)$ & .379 & .705 \\
\hline $\begin{array}{l}\text { BSI- Psychological } \\
\text { distress }\end{array}$ & $64.3(7.6)$ & $67.7(9.0)$ & -2.376 & .019 \\
\hline Somatization & $59.0(8.4)$ & $62.1(9.5)$ & -2.043 & .043 \\
\hline Depression & $60.7(6.9)$ & $60.4(6.1)$ & .339 & .735 \\
\hline Anxiety & $63.8(8.5)$ & $63.7(8.1)$ & .051 & .959 \\
\hline Academic progress (GPA) & $7.5(.41)$ & $7.6(.47)$ & -1.877 & .064 \\
\hline
\end{tabular}

Note. ${ }^{*} \mathrm{p}<.05 ; * * \mathrm{p}<.001 . \mathrm{M}=$ Means; $\mathrm{SD}=$ Standard Deviation 


\section{Differences by age in coping, psychological scales and academic progress}

The strategies used by younger vs older students (Table 4) show that younger students mainly used more cognitive avoidant strategies $(M=52.8$, $S D=7.8, t=4.880, p=.001)$, cognitive avoidance $(M=55.1, S D=9.9, t=$ $5.837, p<.001)$, and more anxiety $(M=65.5, S D=8.1, t=3.299, p=.001)$ than the older students. While older students used more approach coping behaviour $(M=50.9, S D=7.9, t=-2.671, p=.009)$ and problem-solving $(M$ $=50.8, S D=9.4, t=-3.049, p=.003)$ than the young ones, and had better academic performance $(M=7.9, S D=.36, t=-6.537, p<.001)$.

Table 4

Mean differences by age (younger vs older students) in coping (CRI-A), psychological symptoms (BSI) and academic progress (GPA)

\begin{tabular}{lllll}
\hline Coping Strategies & $\begin{array}{c}\text { Younger } \\
\mathrm{n}=85\end{array}$ & $\begin{array}{c}\text { Older } \\
\mathrm{M}=51\end{array}$ & $t$ & $p$ \\
& $\mathrm{M}(\mathrm{SD})$ & $\mathrm{M}(\mathrm{SD})$ & & \\
\hline Approach cognitive coping & $49.9(7.5)$ & $51.1(6.8)$ & -.876 & .383 \\
$\quad$ Logical analysis & $48.9(8.4)$ & $50.4(10.3$ & -.932 & .353 \\
$\quad$ Positive reappraisal & $50.9(8.8)$ & $51.7(6.8)$ & -.512 & .610 \\
Approach behaviour coping & $47.3(7.4)$ & $50.9(7.9)$ & -2.671 & .009 \\
$\quad$ Seeking guidance & $48.6(9.1)$ & $50.9(8.8)$ & -1.473 & .143 \\
$\quad$ Problem solving & $46(8.7)$ & $50.8(9.4)$ & -3.049 & .003 \\
Avoidance cognitive & $52.8(7.8)$ & $46.3(6.9)$ & 4.880 & .0001 \\
coping & & & & \\
$\quad$ Cognitive avoidance & $55.1(9.9)$ & $45.1(8.9)$ & 5.837 & .0001 \\
$\quad$ Acceptance or & $50.6(9.1)$ & $47.6(8.6)$ & 1.919 & .057 \\
$\quad$ resignation & & & & \\
Avoidance behaviour & $51.9(7.3)$ & $51.2(6.2)$ & .539 & .591 \\
coping & & & & \\
$\quad$ Seeking alternative & $51.9(11.3)$ & $51.8(10)$ & .053 & .958 \\
$\quad$ rewards & & & & \\
$\quad$ Emotional discharge & $51.9(8.4)$ & $50.7(8.2)$ & .830 & .408 \\
BSI- Psychological distress & $66.2(8.8)$ & $65.8(7.9)$ & .280 & .780 \\
$\quad$ Somatization & $60.6(9.1)$ & $60.5(9.2)$ & .080 & .937 \\
$\quad \begin{array}{l}\text { Depression } \\
\text { Anxiety }\end{array}$ & $60.4(6.4)$ & $60.8(6.8)$ & -.357 & .721 \\
Academic progress (GPA) & $65.5(8.1)$ & $60.8(7.7)$ & 3.299 & .001 \\
\hline N & $7.4(.40)$ & $7.9(.36)$ & -6.537 & .000 \\
\hline
\end{tabular}

Note. $* \mathrm{p}<.05 ; * * \mathrm{p}<.001 . \mathrm{M}=$ Means; $\mathrm{SD}=$ Standard Deviation 


\section{Bivariate correlations between GPA and psychological scales}

The relationship between academic progress (GPA), coping (CRI-A), and psychological symptoms (BSI) was analyzed considering gender (Table 5). In men, the results show positive relationship between academic progress and psychological distress $(r=.272, p=.030)$, negative relationship between academic progress and cognitive avoidance coping $(r=-.523, p<.001)$ [that includes cognitive avoidance $(r=-.552, p<.001)$, and acceptance $(r=-.247$, $p=.049)]$, and also negative relationship between academic progress and anxiety $(r=-.291, p=.020)$. In women, the results indicate positive relationship between academic progress and problem solving $(r=.289, p=$ $.017)$, psychological distress $(r=.335, p=.005)$, anxiety $(r=.346, p=.004)$, and somatization $(r=.243, p=.046)$, and a negative relationship with positive reappraisal $(r=-.399, p=.001)$, approach behaviour coping $(r=-.312, p=$ $.010)$, cognitive avoidance $(r=-.270, p=.026)$, and approach cognitive coping $(r=-.264, p=.030)$.

Table 5

Correlations between academic progress (GPA), coping (CRI-A) and psychological distress (BSI) by gender

\begin{tabular}{lcc}
\hline Coping Strategies & $\begin{array}{c}\text { Men } \\
\mathrm{n}=68\end{array}$ & $\begin{array}{c}\text { Women } \\
\mathrm{n}=68\end{array}$ \\
\hline Approach cognitive coping & .042 & $-.264^{*}$ \\
Logical analysis & .016 & .009 \\
Positive reappraisal & .065 & $-.399^{* *}$ \\
Approach behaviour coping & .156 & $-.312^{* *}$ \\
Seeking guidance & .159 & .210 \\
Problem solving & .118 & $.289^{*}$ \\
Avoidance cognitive coping & $-.523^{* *}$ & -.190 \\
Cognitive avoidance & $-.552^{* *}$ & $-.270^{*}$ \\
Acceptance or resignation & $-.247^{* *}$ & -.053 \\
Avoidance behaviour coping & -.077 & -.059 \\
Seeking alternative rewards & -.036 & .104 \\
Emotional discharge & -.075 & .039 \\
BSI- Psychological distress & $.272^{*}$ & $.335^{*}$ \\
Somatization & .235 & $.243^{*}$ \\
Depression & .204 & .214 \\
Anxiety & $-.291^{*}$ & $.346^{* *}$ \\
\hline
\end{tabular}

Note. $* \mathrm{p}<.05 ; * * \mathrm{p}<.001$ 


\section{Results of linear regression analysis for significance variables}

To examine the predictive relation between coping strategies (avoidance cognitive coping, cognitive avoidance, and acceptance), BSI (psychological distress and anxiety) and academic progress in men, a linear regression analysis was conducted. The results of the linear regression indicated that psychological distress, cognitive avoidance, and age described $47 \%$ of the variance in academic progress in men $(F=19.686, p<.001)$. In women, a linear regression analysis was conducted between coping strategies (approach cognitive coping, approach behaviour coping, positive reappraisal, problem solving, and cognitive avoidance), BSI scales (psychological distress and anxiety) and academic progress. The results indicated that the positive revaluation, problem solving, anxiety and age described $41 \%$ of the variance in academic progress in women $(F=11.290, p<.001)$. See table 6.

Table 6

Regression model to study the link between psychological scales (BSI) and academic progress $(G P A)$

\begin{tabular}{|c|c|c|c|c|c|c|c|}
\hline \multirow{2}{*}{$\begin{array}{l}\text { Independent } \\
\text { Variable }\end{array}$} & \multirow{2}{*}{$\begin{array}{l}\text { Dependent } \\
\text { Variable }\end{array}$} & \multirow{2}{*}{$\begin{array}{l}\text { Adjusted } \\
R \\
\text { Square }\end{array}$} & \multicolumn{2}{|c|}{$\begin{array}{l}\text { Unstandardized } \\
\text { Coefficients }\end{array}$} & \multirow[t]{2}{*}{$\begin{array}{c}\text { Standardized } \\
\text { Coefficients }\end{array}$} & \multirow[b]{2}{*}{$t$} & \multirow[b]{2}{*}{ Sig. } \\
\hline & & & $B$ & $\begin{array}{l}\text { Std. } \\
\text { Error }\end{array}$ & & & \\
\hline \multicolumn{8}{|l|}{ Men } \\
\hline Constant & Academic & .471 & 7,070 & ,422 & & 16,765 &, 000 \\
\hline $\begin{array}{l}\text { Psychol. } \\
\text { Distress }\end{array}$ & Progress $^{1}$ & & ,017 & ,006 & ,294 & 2,889 &, 005 \\
\hline $\begin{array}{l}\text { Avoidance } \\
\text { cognitive }\end{array}$ & & &,- 023 & ,006 &,- 453 & $-4,148$ & ,000 \\
\hline Age & & & ,021 & ,008 & ,311 & 2,828 & ,006 \\
\hline \multicolumn{8}{|l|}{ Women } \\
\hline Constant & Academic & .413 & 5,808 & ,609 & & 9,542 &, 000 \\
\hline $\begin{array}{l}\text { Positive } \\
\text { Reeval. }\end{array}$ & Progress $^{1}$ & &,- 020 & ,006 &,- 370 & $-3,581$ & ,001 \\
\hline $\begin{array}{l}\text { Problem } \\
\text { solving }\end{array}$ & & &, 014 & ,006 &, 244 & 2,419 & ,019 \\
\hline Anxiety & & & ,019 & ,006 & ,332 & 3,437 &, 001 \\
\hline Age & & &, 020 &, 010 &, 224 & 2,106 &, 039 \\
\hline
\end{tabular}

Notes. Control variables: age

${ }^{\text {a }}$ PSS. Perceived Stress Scales. Raw score.

${ }^{1}$ Grade-point average in the student's academic transcript 


\section{Discussion}

The first goal we set in this study was to describe the problems the subjects explained to us and determine whether any difference existed between men and women. The results indicate that, regardless of gender, the students differ little in the context of what happened, though differences were encountered in the nature, content and participation in the problem.

With regard to nature, the men spoke more of problems in which they felt personally involved; in terms of content, the women described more healthrelated problems than the men; in the participation category, the men described more problems in which friends and/or fellow students were involved.

The men in our sample tended to focus their problem on themselves more than the women, whose concern for their health in this study is in line with previous findings (Ansari et al., 2014) presenting a greater tendency to worry about such problems than male students (Varela-Mato et al., 2012). These differences may be motivated by psychosocial determinants, structural contexts, lifestyles and vulnerabilities inherent in each gender, as Rodriguez et al. (2019) suggest. In the case of interpersonal difficulties, which are a common cause for concern among university students, the male subjects in our study described more conflicts with their peers than the females, a circumstance which may be related to their experiencing greater difficulties in handling social relationships (Hsieh et al., 2014).

The second aim of this study was to compare coping strategies and psychological symptoms on the basis of gender. Pedrelli, Borsari, Lipson, Heinze, and Eisenberg (2016) found that the way university students coped in the face of stressful situations varied according to gender: men drank more alcohol, while women suffered greater psychological distress. Both men and women in our sample employed avoidance coping behaviour such as emotional discharge and seeking alternative rewards. Avoidance coping involves strategies oriented towards denial, minimising or avoiding dealing directly with the situation causing the stress and is closely linked to distress and depression (Alwinet al., 2018). Although the role played by potential stress-generating situations in choosing the style of avoidance coping is unknown, that choice seems likely to produce a broad range of stressors. For example, behavioural avoidance may promote new stress situations, such as 
when emotional discharge aggravates a family conflict or strains relationships at work (Davoren at el., 2015), or when the search for alternative reinforcement (as in alcohol, tobacco or cannabis consumption) leads to additional problems (Butler, Dodge, \& Faurote, 2010).

In our sample, the women employed more logical analysis and acceptance or resignation and presented more distress and somatisation than the men. Holahan et al. (2005) suggest that women's use of cognitive strategies may be due to the role played by rumination, linked to the presence of depressive symptoms and more common in women than in men (Holahan et al., 2005). Future studies should analyze the possible role of rumination in the mediation between coping strategies and psychological distress. Acceptance or resignation coping has been associated with a higher risk of psychological distress and even increased suicidal ideation among Chinese university students (Tang \& Qin, 2015). The greater presence of psychological distress in women than in men is consistent with results obtained by other authors (Deasy et al., 2014).

With regard to age, Bewick et al. (2010) found that students in the first years show more stress than others. Our results suggest that younger university students present a more avoidance-based coping profile and experience more anxiety than their older colleagues. It could be thought that older students would suffer more stress because they are under more pressure from financial problems or difficulties in finding a job; however, our findings show that anxiety is more present in the young. This could be connected with their adaptation to the academic environment which, in turn, may be linked to the resources available to them and their use of ineffective strategies that hinder their adaptation. In our study, young students tended to use less adaptive strategies to combat stress, a finding in line with literature on the subject which indicates that younger students are more likely to ignore their mental health (Davoren et al., 2015).

The final aim of our study was to analyze the predictive relationship of coping strategies and psychological symptoms in the academic progress of men and women. One of the main findings of this study is that academic progress varies according to gender and that coping, psychological symptoms and age play a significant role in performance. Greater academic progress in men can be explained by reduced cognitive avoidance coping and the presence of a certain degree of stress or psychological distress, which seems to increase 
with age. In women, better academic performance seems to be related to a reduction in positive reappraisal together with increased approach coping and anxiety, and the latter also seems to rise with age.

In our sample, both men and women needed a certain amount of distress or anxiety in order to achieve improved progress. This coincides with the explanatory model of optimal challenge proposed by Csikszentmihalyi (2014), which holds that the most motivating activities are those in which there is initially an imbalance between the skills the individual has and those necessary to meet the challenges presented by a situation, but that through reasonable voluntary effort this imbalance can be corrected. However, should this not occur, two different outcomes are possible: if the challenge is greater than the individual's skills, the resulting difficulty produces an excess of anxiety; and if the skills far outweigh the challenges, the individual becomes bored and feels less motivated. This suggests that in an increasingly competitive academic environment the absence of stress or anxiety could reduce students' performance.

Likewise, a reduced use of avoidance strategies would also be linked to improved academic progress. Avoidance coping has traditionally been considered a maladaptive strategy in the academic context (Gustems \& Calderon, 2013); students that resort to it tend to consume more alcohol (Butler et al., 2010) and tobacco (Davoren et al., 2015), and present more eating disorders (Tavolacci et al., 2013), depression (Hye-Yun, 2016) and psychological distress (Panova et al., 2019). However, coping strategies are not always prejudicial. When the situation is inevitable (such as the death of a family member or losing a job) cognitive avoidance may prove adaptive (Gustems et al., 2019), while in the university context students are expected to adopt a more proactive attitude, since the challenges they have to overcome are usually within their capabilities.

Although approach coping is related to reduced depression (Highighatgou \& Peterson, 1995), it seems a reduction in positive reappraisal plays a role in the improvement of academic progress in women. This could be related to their propensity for rumination: a moderate use of cognitive reappraisal may be adaptive and positive, but used in excess could lead to despair, passivity and symptoms such as depression, a suggestion put forward by Holahan et al. (2005). As negative thinking has been linked to maladaptive strategies and anxiety (Mahmoud, Staten, Lennie, \& Hall, 2015), social support may help 
students better cope with the stressful situations encountered at university and reduce avoidance behaviours (Saïas et al., 2014).

\section{Conclusions}

The ability of teacher education students to withstand the growing pressure of university life is crucial for their well-being, academic progress and training. The results of this study demonstrate that the adaptation mechanisms of younger students, both male and female, are not well suited to this purpose, as they primarily employ conflict avoidance strategies. Gender analysis should be taken into account in future studies of university students, especially when related to degrees associated with the initial education of primary school teachers, to ensure that their curricula address the different needs of male and female undergraduates.

It is apparent that the teachers of this new millennium have, among other challenges, to confront the inequalities that afflict our society and to find a way of bringing the curriculum to people of all cultures (Byrd, 2012). The happiness of future generations depends on our teaching them to be happy people through the exercise of good behavior. The selection of teachers before and after their training should be based on an appropriate profile which allows them to feel and provoke well-being, to be a reference in this respect for their students and to stay in the profession for a long time. Teacher training must be an opportunity for exploring possibilities in order to improve academic achievement, improve students' coping strategies, and reduce psychological distress among them.

The results of this study provide information that is potentially useful for changing and improving coping strategies through the development of social networks involving the student body and, in particular, its younger members. These could include a system of cross-curricular tutorials that support students in the transition and challenges of the new academic environment, a guide to help first-year students establish reasonable goals, the organisation of extracurricular activities in which students could develop their social skills, and initiatives to foster their desire for knowledge and technology innovation. All of these initiatives would enhance their potential and establish a sound basis for their professional future. 
In future research it would be interesting to study the role of social support in relation to university students' commitment and academic progress.

\section{References}

Aldwin, C. M., Iragashi, M., Gilmer, D. F., \& Levenson, M. R. (2018). Health, Illness and Optimal Aging. Springer.

Ansari, W. E., Oskrochi, R., \& Haghgoo, G. (2014). Are Students' Symptoms and Health Complaints Associated with Perceived Stress at University? Perspectives from the United Kingdom and Egypt. International Journal of Environmental Research and Public Health, 11(10), 998110002. doi:10.3390/ijerph111009981

Bewick, B., Kotusopoulou, G., Miles, J., Slaa, E., \& Barkham, M. (2010). Changes in undergraduate students' psychological well-being as the progress through university. Studies in Higher Education, 35(6), 633645. doi:10.1080/03075070903216643

Butler, A. B., Dodge, K. D., \& Faurote, E. J. (2010). College student employment and drinking: a daily study of work stressors, alcohol expectancies, and alcohol consumption. Journal of Occupational Health Psychology, 15, 291-303. doi:10.1037/a0019822

Byrd, G. (2012). Social Studies Education as a Moral Activity: Teaching towards a just society. Educational Philosophy and Theory, 44(10), 1073-1079. doi: 10.1111/j.1469-5812.2011.00761.x

Coertjens, L., Brahm, T., Trautwein, C., \& Lindblom, S. (2017). Students' transition into higher education from an international perspective. Higher Education, 73(3), 357-369. doi: 10.1007/s10734-016-0092-y

Csikszentmihalyi, M. (2014). Flow and the Fundations of Positive Psychology. SpringerLink.

https://link.springer.com/book/10.1007/978-94-017-9088-8

Davoren, M. P., Dhiely, F., Byrne, M., \& Perry, I. J. (2015). Hazardous alcohol consumption among university students in Ireland: a crosssectional study. BMJ Open 2015(5), e006045. doi: 10.1136/bmjopen2014-006045

Deasy, C., Coughlan, B., Pironom, J., Jourdan, D., \& Mannix-McNamara, P. (2014). PLoS ONE, 9(12): el15193. doi: 10.1371/journal.pone.0115193 
Deasy, C., Coughlan, B., Pironom, J., Jourdan, D., \& Mannix-McNamara, P. (2016). Psychological distress and help seeking amongst higher education students: findings from a mixed method study of undergraduate nursing/midwifery and teacher education students in Ireland. Irish Educational Studies, 35(2), 175-194.

Derogatis, L. R. (2001). Brief Symptom Inventory (BSI-18). Administration, scoring and procedures manual. NCS Pearson, Inc.

Farley, A. N., Clayton, G., \& Kaka, S. J. (2018). Linking teacher education to redesigned systems of accountability: A call for multiple measures in pre-service teacher effectiveness. Education policy analysis archives, 26(12), 1-11. doi: 10.14507/epaa.26.2920.

Forns, M., Amador, J. A., Kirchner, T., Martorell, B., Zkemberanini, D., \& Muro, P. (2004). Sistema de codificación y análisis diferencial de los problemas de los adolescentes. Psicothema, 16(4), 646-653.

Gustems, J., \& Calderon, C. (2013). Coping strategies and psychological wellbeing among teacher education students. European Journal of Psychology of Education, 28(4), 1127-1140. doi: 10.1007/s10212-012$0158-\mathrm{x}_{-}$

Gustems, J., Calderon, C., Batalla, A., \& Esteban, F. (2019). Role of Coping Responses in the Relationship between perceived stress and Psychological Well-.being in a Sample of Spanish Educational Teacher Students. Psychological Reports, 122(2), 380-397. doi: 10.1177/0033294118758904.

Haghighagou, H., \& Peterson, C. (1995). Coping and depressive symptoms among Iranian students. Journal of Social Psychology, 135(2), 175180.

Hofman, R. H., Hofman, W. H. A., \& Gray, J. M. (2015). Three conjectures about school effectiveness: An exploratory study. Cogent Education, 2(1), 1-13. doi: 10.1080/2331186X.2015.1006977

Holahan, C. J., Moos, R. H., Holahan, C. K., Brennan, P. L., \& Schutte, K. K. (2005). Stress Generation, Avoidance, and Depressive Symptoms: A 10-year Model. Journal of Consulting and Clinical Psychology, 73(4), 658-666.

Hollingshead, A. B. (2011). Four factor index of social status. Yale Journal of Sociology, 8, 21-52. 
Hsieh, M.-C., Wang, T.-S., Fan, C.-P., \& Huang, C.-I. (2014). A study of the emotional intelligence and interpersonal relationships of college students in southern Taiwan. Universal Journal of Management, 2(8), $133-138$.

Hye-Yun, J. (2016). The Convergence Influence of Life Stress, Depression and Ego Resiliency on College Life Adaptation in Nursing Students. Journal of Digital Convergence, 14(7), 259-268. doi: 10.14400/JDC.2016.14.7.259

Jenzer, T., Read, J. P., Naragon-Gainey, K., \& Prince, M. A. (2019). Coping trajectories in emerging adulthood: The influence of temperament and gender. Journal of Personality, 87(3), 607-619.

Kember, D., \& Leung, D. Y. P. (2006). Characterizing a teaching and learning environment conducive to making demands on students while not making their workload excessive. Studies in Higher Education, 31(2), 185-198.

Kirchner, T., Forns, M., Muñoz, D., \& Pereda, N. (2008). Psychometric properties and dimensional structure of the Spanish version of the Coping Responses Inventory-Adult Form. Psicothema, 20(4), 902-909.

Kwan, M. Y., Arbour-Nicitopoulus, K. B., Duku, E., \& Faulkner, G. E. (2016). Patterns of multiple health risk-behaviours in university students and their association with mental health: application of latent class analysis. Health Promotion and Chronic Disease Prevention in Canada, 36(8), 163-170.

Maandag, D. W., Helms-Lorenz, M., Lugthart, E., Verkade, A. T., \& Van Veen, K. (2017). Features of effective professional development interventions in different stages of teacher's careers. A review of empirical evidence and underlying theory. Groningen: University of Groningen.

https://www.nro.nl/wpcontent/uploads/2017/08/Effectiveness-of-professional-developmentinterventions-in-different-teacher-career-stages.pdf

Mahmoud, J. S. R., Staten, R. T., Lennie, T. A., \& Hall, L. A. (2015). The Relationships of Coping, Negative Thinking, Life Satisfaction, Social Support, and Selected Demographics with Anxiety of Young Adult College Students. Journal of Child and Adolescent Psychiatric Nursing, 28(2), 97-108. doi: 10.1111/jcap.12109. 
McCarthy C. J., Lineback S., Fitchett P. G., Lambert R.G., Eyal, M., \& Boyle L. H. (2017). The Role of Culture and Other Contextual Factors in Educator Stress. In McIntyre T., McIntyre S., Francis D. (eds.), Educator Stress. Aligning Perspectives on Health, Safety and WellBeing (pp. 157-177). Springer.

Moos, R. H. (1993). Coping responses inventory: CRI-Adult Form professional manual. Psychological Assessment Resources.

National Commission for the Protection of Human Subjects of Biomedical and Behavioral Research. (1978). The Belmont Report, Ethical Principle and Guidelines for the protection of human research subjects. DHEW.

Panova, T., Carbonell, X., Chamarro, A., \& Puerta-Cortes, D. X. (2019). Specific smartphone uses and how they relate to anxiety and depression in university students: a cross-cultural perspective. Behaviour \& Information Technology, 39(9), 944-956. doi: 10.1080/0144929X.2019.1633405

Patiño, C., \& Kirchner, T. (2010). Stress and Psychopathology in LatinAmerican immigrants: the role of coping strategies. Psychopathology, 43(1), 1-68. doi: 10.1159/000255959

Pedrelli, P., Borsari, B., Lipson, S. K., Heinze, J. E., \& Eisenberg, D. (2016). Gender Differences in the Relationships among Major Depressive Disorder, Heavy Alcohol Use, and Mental Health Treatment Engagement among College Students. Journal of Studies on Alcohol and Drugs, 77(4), 620-628. doi:10.1111/j.1751-9861.1999.tb00056.x

Reilly, D., Neumann, D. L., \& Andrews, G. (2015). Sex differences in mathematics and science achievement: A meta-analysis of National Assessment of Educational Progress assessments. Journal of Educational Psychology, 107(3), 645-662. doi: 10.1037/edu0000012

Rodriguez, J. M., Karlamangla, A. S., Gruenewald, T. L., Miller-Martinez, D., Merkin, S. S., \& Seeman, T.E. (2019). Social stratification and allostatic load: shapes of health differences in the MIDUS study in the United States. Journal of Biosocial Science, 51(5), 627-644.

Saïas, T., du Roscoät, E., Véron, L., Guignard, R., Richard, J. B., Legleye, S., Sauvade, F., Kovess, V., \& Beck, F. (2014). Psychological distress in French college students: demographic, economic and social stressors. 
Results from the 2010 National Health Barometer. BMC Public Health, $14,256$.

Singh, A., \& Upadhyay, A. (2008). Age and sex differences in academic stress among college students. Social Science International, 24(1), 78-88.

Tang, F., \& Qin, P. (2015). Influence of Personal Social Network and Coping Skills on Risk for Suicidal Ideation in Chinese University Students. PLoS ONE, 10(3). doi: 10.1371/journal.pone.0121023

Tavolacci, M. P., Ladner, J., Grigioni, S., Richard, L., Villet, H., \& Dechelotte, P. (2013). Prevalence and association of perceived stress, substance use and behavioural addictions: a cross-sectional study among university students in France, 2009-2011. BMC Public Health, 13,724 .

Varela-Mato, V., Cancela, J. M., Ayan, C., Martín, V., \& Molina, A. (2012). Lifestyle and health among spanish university students: differences by gender and academic discipline. International Journal of Environmental Research and Public Health, 9, 2728-2741.

\section{Josep Gustems-Carnicer, Caterina Calderon, Diego Calderon-}

Garrido and Carolina Martin-Piñol are professors and/or researchers at the University of Barcelona.

Contact Address: Correspondence regarding this article should be addressed to Caterina Calderon, email: ccalderon@ub.edu 